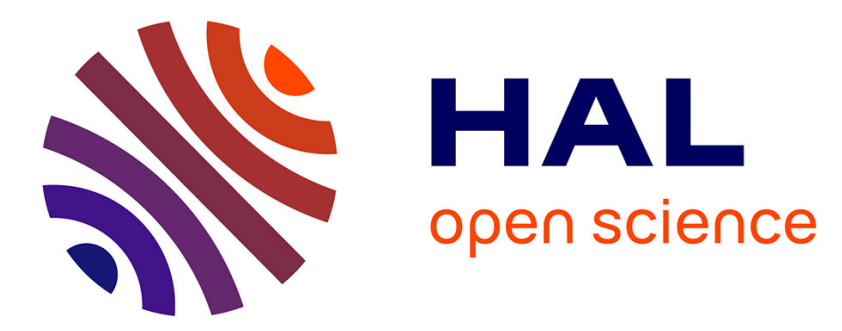

\title{
A Universal Index of Uterine Discharge Symptoms from Calving to 6 Weeks Postpartum
}

\author{
Justyna J. Gorzecka, Nicolas N.C. Friggens, Carsten C. Ridder, Henrik H.
}

Callesen

\section{- To cite this version:}

Justyna J. Gorzecka, Nicolas N.C. Friggens, Carsten C. Ridder, Henrik H. Callesen. A Universal Index of Uterine Discharge Symptoms from Calving to 6 Weeks Postpartum. Reproduction in Domestic Animals, 2011, 46 (1), pp.100-107. 10.1111/j.1439-0531.2010.01600.x . hal-01000649

\section{HAL Id: hal-01000649 \\ https://hal.science/hal-01000649}

Submitted on 29 May 2020

HAL is a multi-disciplinary open access archive for the deposit and dissemination of scientific research documents, whether they are published or not. The documents may come from teaching and research institutions in France or abroad, or from public or private research centers.
L'archive ouverte pluridisciplinaire HAL, est destinée au dépôt et à la diffusion de documents scientifiques de niveau recherche, publiés ou non, émanant des établissements d'enseignement et de recherche français ou étrangers, des laboratoires publics ou privés. 


\title{
A Universal Index of Uterine Discharge Symptoms from Calving to 6 Weeks Postpartum
}

\author{
J Gorzecka $^{1,2}$, NC Friggens ${ }^{3}$, C Ridder ${ }^{1,4}$ and H Callesen ${ }^{1}$ \\ ${ }^{1}$ Faculty of Agricultural Sciences, Aarhus University, Tjele, Denmark; ${ }^{2}$ Faculty of Life Sciences, University of Copenhagen, Copenhagen, Denmark; \\ ${ }^{3}$ INRA, French National Institute of Agricultural Research, AgroParisTech, Paris, France; ${ }^{4}$ Lattec I/S, Hillerød, Denmark
}

\section{Contents}

In this paper, a new uterine discharge index (D-index) was created and tested. It was based on a principal component analysis (PCA) of clinical findings of classical uterine discharge symptoms and rectal temperature during the postpartum period of dairy cattle. The PCA analysis revealed how uterine discharge features relate to each other and how they cluster together possibly representing different degrees of uterine inflammation. The D-index was the result of the multivariate PCA-analysis, and the D-index gives a continuous value between 0 and 10 . It was demonstrated that the same scale, i.e. the D-index, can be used without any adjustment from 1 to 6 weeks post-calving. It is valid for any type of uterine discharge without defining the type of infection or differentiating between infection and contamination. The D-index was tested using the uterine involution data. Uterine involution was significantly delayed in the high-D-index group of cows. Similarly, in the test with all cows, involution was progressively delayed and the rate of involution of the pregnant horn was slowed down with the increase of the D-index values. It is concluded that the D-index can be a new practical, universal, tool for improved management of dairy cows in the postpartum period under commercial conditions.

\section{Introduction}

Uterine inflammation is an important risk factor in dairy cattle reproduction, because it is associated with lower conception rates, increased intervals from calving to first service or to conception and culling of more animals for failure to conceive (Borsberry and Dobson 1989; LeBlanc et al. 2002). Besides local inflammatory effects in the uterus, the condition results in disturbances to ovarian function and to signalling from the hypothalamus and pituitary gland, which may cause negative changes in ovarian activity and the quality of oestrous cycle (Battaglia et al. 2000; Sheldon et al. 2002; Sheldon and Dobson 2004; Herath et al. 2007; Miller et al. 2007).

From a clinical point of view, i.e. as a basis for treatment and profylaxis, it is important to be able to characterize the relationship between degree of uterine inflammation and fertility. However, in practice, there are problems in assessing this relationship, and improving our ability to quantify degree of uterine inflammation would thus be a valuable step towards dealing with its impact on fertility.

Uterine infection can be diagnosed by bacteriological, cytological or histological examination, but these methods are not useful under field conditions where diagnosis and eventual treatment have to be performed immediately. Therefore, evaluation of uterine discharge collected from the vagina is considered as an effective, but also simple and non-invasive method in the field
(Bretzlaff 1987; LeBlanc et al. 2002; Sheldon et al. 2006). It has been shown that uterine discharge reflects well the bacterial uterine infection and immune response (Williams et al. 2005) and that the presence of purulent discharge in the vagina is associated with the presence of pathogenic bacteria in the uterus (Dohmen et al. 1995; Huszenicza et al. 1999; Williams et al. 2005). The types of uterine infection, based mainly on the uterine discharge, have been described in the literature and reviewed by Sheldon et al. (2006).

For assessing the infection's severity, scoring systems have been described that include some of the features of the discharge, which are frequently correlated, such as presence of pus, blood, smell and sometimes additional information concerning size and position of the uterus and cervix. However, these scoring systems are not uniform and are also limited to certain time periods after calving or certain types of uterine infection, for instance applying only to endometritis (Murray et al. 1990; Dohmen et al. 1995; Sheldon and Noakes 1998; Huszenicza et al. 1999; Williams et al. 2005). Furthermore, these systems aim to identify specific classes of infection (healthy, subclinical and clinical); they do not seek to quantify the underlying degree of inflammation.

In our study, a multivariate approach (principal components analysis, PCA) was used as a method for investigating general biological patterns of the discharge features in the postpartum period. The PCA method is particularly useful for situations where it is difficult or even not possible to measure something directly - such as 'degree of uterine inflammation', and it is also suitable for dealing with correlated data.

The main purpose of the study was to use this analysis to develop a universal index of uterine inflammation clinical symptoms, which is continuous and not limited by time after calving and type of uterine infection.

\section{Materials and Methods Animals}

The data collection was done from January to December 2008 in the herd at the Danish Cattle Research Center in Foulum, Denmark. In total, 126 dairy cows in lactation 1 to 5 were examined: 86 Danish Holstein and 40 Danish Jersey. The cows were kept in 2 groups of Danish Holstein and 1 group of Danish Jersey in a loose housing system and they were milked by VMS (Voluntary Milking System, DeLaval, Tumba, Sweden). The average milk yield was $9640 \mathrm{~kg} \mathrm{ECM}$, and the cows were fed ad libitum with a total mixed ration containing 50\% 
roughage (approx. 50/50 corn silage and grass silage) and $50 \%$ standard dairy concentrate.

\section{Clinical examination}

The cows were examined once weekly by the same person, starting from week 1 until week 6 after calving. All the examinations included (i) measuring rectal temperature, (ii) transrectal palpation of uterus and ovaries (presence of ovarian cysts was recorded), (iii) transrectal ultrasound scanning of the uterus and (iv) collecting uterine discharge.

At each ultrasound scanning, faeces from the rectum was first removed, and the uterine involution rate was determined based on measurement of the diameter of the uterine cervix (in the middle of the cervix) and the diameter of both uterine horns $(5 \mathrm{~cm}$ from the bifurcation). This was measured using built-in calipers in the ultrasound scanner (Aloka,Co.Ltp, Japan) with a 5.0 $\mathrm{MHz}$ linear-array transducer.

Uterine discharge was collected from the vagina by hand with rectal glove and lubricant, after cleaning of the vulva with paper towels. Each sample of collected discharge was photographed and scored separately for five features (Table 1): proportion of pus, amount, consistency, smell and colour (content of blood).

\section{Modelling and statistical analysis}

\section{Scoring system for uterine discharge}

The scores for uterine discharge symptoms used in the clinical examinations do need, a priori, to correlate with the severity of uterine infection as experienced by the cow. Even if such a correlation exists, it may not relate linearly to the scoring system scale. Thus, rather than assume some form of relation between the different score classes, it was assumed that they were independent. All score classes (Table 1) were therefore transformed into class-variables. For example, 'consistency' score 1 was transformed into 'watery' or 'not watery'. Thus, the single consistency-variable, which had been given values from 1 to 4 (watery, semi-viscous, mucus-like, dense), was transformed into four binary class-variables and each cow (sample) will have the value 1 (one) in only one of these classes and 0 (zero) in the rest of the classes.

Transforming all score-variables resulted in obtaining class-variables (Fig. 1): pus = 'pus0', 'pus1', 'pus2', 'pus3'; amount = 'amount0', 'amount1', 'amount2', 'amount3'; consistency = 'watery', 'semi-viscous', 'mucus-like', 'dense'; colour = 'no blood', 'pink', 'red', 'brown', 'black'. Only the variable 'smell' was not changed, because it already had numeric values 0

Table 1. Scoring of uterine discharge

\begin{tabular}{lccccc}
\hline & \multicolumn{5}{c}{ Score } \\
\cline { 2 - 6 } Discharge features & 0 & 1 & 2 & 3 & 4 \\
\hline Proportion of pus & No & Flecks & $\leq 50 \%$ & $>50 \%$ & - \\
Amount & No & $<1$ handful & 1 handful & $>1$ handful & - \\
Consistency & No & Watery & Semi-viscous & Mucus-like & Dense \\
Smell & No & Yes & - & - & - \\
Colour & No & Pink & Red & Brown & Black \\
\hline
\end{tabular}

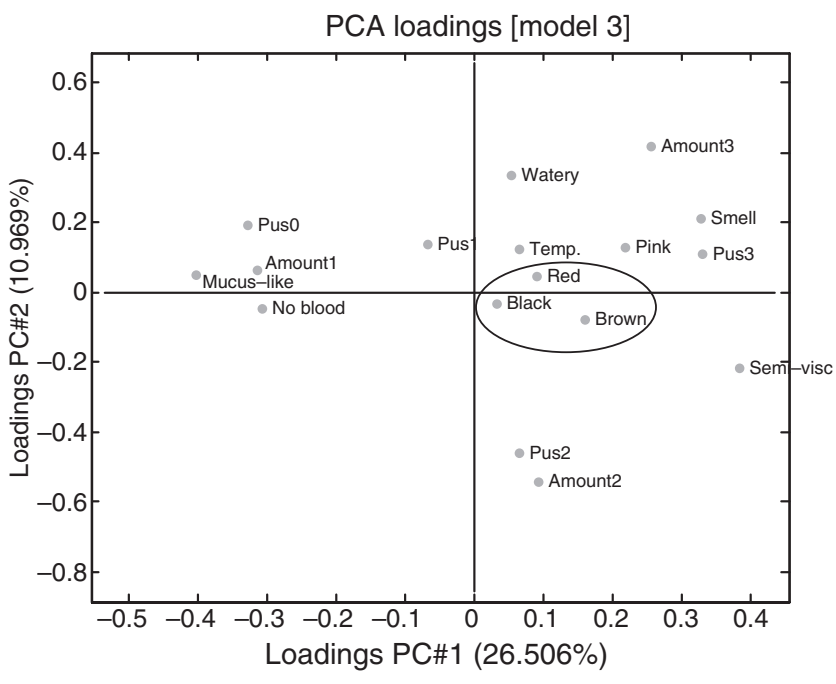

Fig. 1. Plot of PCA loadings for principal components 1 and 2, showing the relations between all the new class-variables. The close correlation between colour-variables 'red', 'brown' and 'black' is indicated

(no) and 1 (yes). Finally, the 'dense' consistency was excluded from the scale because of too few cases (only two cases in the whole study) that could falsely influence relations in the PCA model (Esbensen 2002).

\section{Missing values in the database}

When the variable amount $=0$, the rest of the discharge features were missing per definition, and these observations were therefore excluded from the PCA model. These animals were assumed to be healthy, but this rule would not concern cows with pyometra, where a uterus filled with pus is associated with closed cervix and a lack of discharge in the vagina (Sheldon et al. 2006). However, in the present study no pyometra cases were found.

\section{Principal component analysis}

The collected data of uterine discharge symptoms and rectal temperature were analyzed using LATENTIX 2.00 (Latent5, Copenhagen, Denmark, http://www.latentix.com), which is a chemometric software for multivariate data analysis, including principal components analysis (PCA), frequently used for explorative data structure modelling. PCA reveals interrelationship between all measurements (variables) and observations (objects) simultaneously and decomposes the data in order to detect and model latent structures ('hidden phenomena') (Esbensen 2002).

Before creating the PCA model, the data were autoscaled to mean 0 and SD 1. Using these scaled data the software calculated loadings coefficients for each variable and for each principal component (Table 2). Loading coefficients, i.e. describing the relationship between all variables, were used to calculate the scores, i.e. the position of all observations in the PCA model.

\section{Preparation for the main analysis}

In the first analysis a loadings plot for principal components 1 and 2 was made, representing relations 
between all 17 new class-variables (Fig. 1). As seen from Fig. 1, the colour-variables 'red', 'black' and 'brown' are closely correlated. From the point of view of PCA modelling, these colour-variables have a similar meaning in the model. From the clinical point of view it was often difficult to distinguish between dark brown and black discharge and between red and brown discharge, which was often a mixture of these colours. Therefore, the colour-variables 'red', 'black' and 'brown' were transformed into one variable: 'brownish'. This simplification did not change the relations between other variables in the model (Fig. 2).

\section{Index of uterine discharge symptoms (D-index)}

An index of severity of discharge symptoms (D-index) was created on the basis of the first principal component, by multiplying the original measured variables with $\mathrm{p}^{*}$ coefficients. The $\mathrm{p} 1 *$ coefficients are $\mathrm{p} 1$ coefficients adjusted for the autoscaling of the data. After this calculation the index ranged from -3 to 4 , like in the scores plot (Fig. 3). Therefore, in order to simplify the scale and for convenience, it was linearly transformed into a $0-10$ range (Fig. 8). For this range new 'discharge coefficients' (D-coefficients) were calculated (Table 3). When summed D-coefficients of the original measured variables (and adding the offset) resulted in the D-index, which ranges from 0 to 10 .

\section{Testing of the D-index}

The uterine involution process was estimated by regressing the diameters of the cervix and the previously pregnant uterine horn on time from calving using MinitaB 9 software (http://www.minitab.com). In order to test the D-index, two tests were made:

Extreme animals: Groups of extreme cases were extracted: one group of 12 cows with discharge symptoms index 0-2 during the whole period of examinations, and

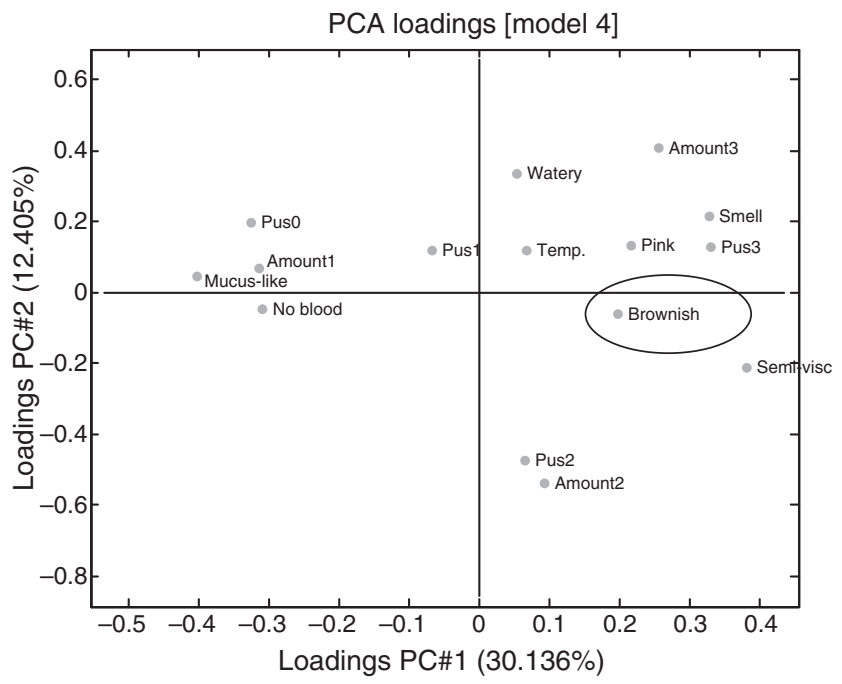

Fig. 2. PCA model with transformed 'brownish' variable, which did not change the relations between the other variables one group of 17 cows with discharge symptoms index $8-10$ in at least two successive examinations. All of these examinations occurred during the first 3 weeks after calving. The first group, called low-D-index was assumed to have a better uterine health than the second group, called high-D-index. The regression equation $\ln (Y)=\ln (a)+b \times t+k \cdot \inf +l \times \inf \times \mathrm{t}$ was used to estimate the influence of uterine infection on the rate of uterine involution in two described groups (low$\mathrm{D}$-index $=0$ and high-D-index $=1$ ), where $\mathrm{Y}$ is the diameter of either the pregnant horn or cervix.

All animals: The next test of uterine involution was performed using all animals. The maximum value of the discharge index within 21 days after calving was used as a constant value of uterine inflammation for each cow. The regression equation $\ln (Y)=\ln (a)+b \times t+k \times$ $\max D$-index $+l \times \max D$-index $\times t$ was used to estimate the influence of the value of the D-index on the rate of uterine involution.

\section{Results}

\section{Interpretation of the PCA model}

In Fig. 3 (lower panel), the naturally occurring relationships between the uterine discharge scores revealed by the PCA are shown for the two main principal components, 1 and 2, that together accounted for $42.5 \%$ of a total variance. Symptoms that are close together are highly correlated (e.g. smell and pus3). Uterine discharge scores that are at opposing ends of a PC (e.g. pus0 and pus 3 on $\mathrm{PC} \# 1$ ) indicate features that differentiate different types of discharge and different severity of uterine inflammation clinical symptoms. In this context, $\mathrm{PC} \# 1$ is the component with the maximum variance and differentiated symptoms into 'clean uterus' and 'not clean uterus' groups. This might be interpreted as 'healthy' uterus (with small amount of normal mucus) and 'sick' uterus (with high scores of discharge symptoms). The distributions of the individual scores from each cow observation are shown in the upper panel of Fig. 3. Coefficients for the first two principal components are presented in Table 3 . The remaining coefficients for further PCs and the percent of variance, which they accounted for, are presented in Table 2.

\section{Time factor in the model}

In Fig. 4 a scores plot is presented, which is shaded according to days from calving (DFC). The observations with high values of $\mathrm{PC} \# 1$ tended to occur closer to the calving, especially within the first 3 weeks after calving. In order to evaluate whether the relationship between discharge scores was affected by DFC, a DFCvariable was added to the PCA model. Adding this variable did not impair the model; neither did it affect the relations between the other variables or the percent of explained variation. It just showed that the proportion of cows having 'not clean uterus' decreased with time (Fig. 5 - note that due to the rotational ambiguity of PCA, the sign of the loadings is reversed). In order to further check the stability of the model across time from 

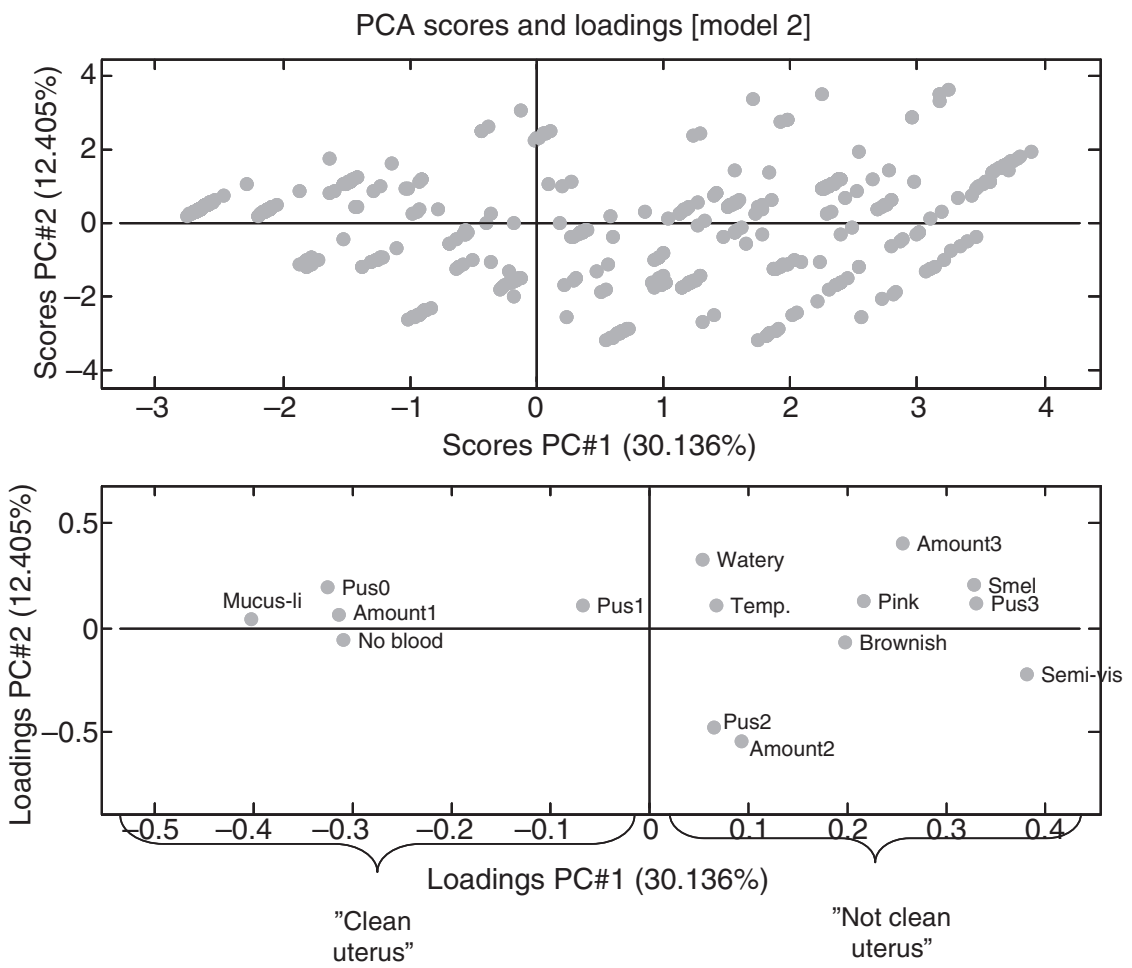

Fig. 3. PCA model of scores and loadings for uterine discharge symptoms. The position of the objects (each examination) in scores plot (upper panel) was calculated using coefficients (p1, p2) for each variable. The loadings plot (lower panel) shows how the variables are correlated with each other. PC1 differentiates symptoms into 'clean' and 'not clean' uterus

Table 2. Loadings and percent of explained variance for PC1 to PC\#12

\begin{tabular}{|c|c|c|c|c|c|c|c|c|c|c|c|c|}
\hline Loadings & $\mathrm{PC} \# 1$ & $\mathrm{PC} \# 2$ & PC\#3 & $\mathrm{PC} \# 4$ & $\mathrm{PC} \# 5$ & PC\#6 & PC\#7 & PC\#8 & PC\#9 & PC\#10 & PC\#11 & $\mathrm{PC} \# 12$ \\
\hline Temp. & 0.06 & 0.12 & 0.05 & 0.32 & -0.20 & 0.02 & -0.17 & -0.89 & -0.10 & 0.02 & 0.03 & 0.00 \\
\hline Smell & 0.33 & 0.22 & 0.14 & -0.06 & -0.08 & -0.03 & -0.02 & 0.02 & 0.06 & -0.84 & -0.32 & 0.00 \\
\hline No blood & -0.31 & -0.04 & 0.21 & -0.48 & 0.02 & 0.35 & -0.07 & -0.17 & -0.06 & -0.07 & -0.03 & 0.00 \\
\hline Pink & 0.21 & 0.14 & 0.15 & 0.01 & -0.49 & -0.61 & -0.16 & 0.18 & -0.03 & 0.22 & 0.00 & 0.00 \\
\hline Brownish & 0.20 & -0.06 & -0.35 & 0.55 & 0.35 & 0.06 & 0.21 & 0.06 & 0.09 & -0.09 & 0.04 & 0.00 \\
\hline Watery & 0.05 & 0.34 & -0.42 & -0.19 & -0.09 & 0.02 & 0.25 & 0.02 & -0.69 & -0.05 & 0.16 & 0.31 \\
\hline Semi-visc & 0.38 & -0.21 & 0.24 & 0.01 & 0.18 & 0.14 & -0.14 & 0.01 & -0.10 & 0.26 & -0.40 & 0.67 \\
\hline Mucus-like & -0.40 & 0.05 & -0.05 & 0.08 & -0.14 & -0.16 & 0.03 & -0.02 & 0.42 & -0.23 & 0.31 & 0.68 \\
\hline pus0 & -0.33 & 0.20 & 0.20 & 0.20 & -0.09 & -0.03 & 0.50 & 0.01 & -0.02 & 0.12 & -0.45 & -0.01 \\
\hline pus1 & -0.07 & 0.12 & -0.52 & -0.27 & 0.28 & -0.26 & -0.45 & -0.12 & 0.16 & 0.04 & -0.28 & 0.00 \\
\hline pus2 & 0.06 & -0.47 & -0.19 & 0.15 & -0.49 & 0.33 & -0.23 & 0.16 & -0.12 & -0.15 & 0.12 & 0.00 \\
\hline pus3 & 0.33 & 0.13 & 0.36 & -0.13 & 0.33 & -0.07 & 0.05 & -0.06 & 0.01 & -0.02 & 0.56 & 0.01 \\
\hline amount 1 & -0.32 & 0.07 & 0.22 & 0.30 & 0.21 & -0.08 & -0.39 & 0.17 & -0.36 & -0.12 & 0.01 & 0.00 \\
\hline amount 2 & 0.09 & -0.53 & -0.10 & -0.26 & 0.01 & -0.34 & 0.40 & -0.25 & 0.01 & -0.09 & -0.03 & 0.00 \\
\hline amount3 & 0.25 & 0.41 & -0.14 & -0.08 & -0.23 & 0.39 & 0.05 & 0.05 & 0.38 & 0.22 & 0.01 & 0.00 \\
\hline$\%$ expl. variance & 30.1 & 42.5 & 53.2 & 62.5 & 70.4 & 77 & 83.4 & 89.3 & 94.3 & 97.6 & 99.9 & 100 \\
\hline
\end{tabular}

calving, the data were divided into two time intervals: weeks 1-3 and weeks 4-6 (Fig. 6). Objects in weeks 1-3 are spread proportionally in the space of the model. Objects in weeks 4-6 are more clustered in the left part of the model, which suggests that the uterus is more 'clean' in this period of time.

The model based only on data from weeks $1-3$ was used to predict scores for weeks 4-6. The comparison of predicted scores with the model is a measure of the goodness of fit of the sample to a particular principal component model. The software calculates confidence limits for the scores applying the Student's $t$-distribution (Wise and Gallagher 2000). As can be seen in Fig. 7, all predicted objects from week 4-6 remain in the ellipse, which shows the $95 \%$ confidence interval, demonstrating the stability of the model across time (Jackson 1991; Esbensen 2002). Therefore, it was decided to create only one common discharge index for all 6 weeks after calving.

\section{Index of uterine discharge symptoms (D-index)}

The index of discharge symptoms was created on the basis of the first principal component and ranges from 0 to 10 . Fig. 8 presents the numerical relation between the PCA-scores and D-index. PCA-scores are shaded according to the value of the D-index.

\section{Testing of the D-index}

\section{Uterine involution in extreme groups}

There was a significantly greater intercept for high-index cows when compared with low-index cows in the regression of pregnant horn diameter on DFC, but no 
Table 3. Coefficients p1, p2 used for calculating of PC1 and PC\#2, coefficients $1^{*}$ (which are $\mathrm{p} 1$ coefficients adjusted for the autoscaling of the data) used for creating an index of severity of discharge symptoms (D-index) and D-coefficients used for calculating this index after the linear transformation into a $0-10$ range

\begin{tabular}{|c|c|c|c|c|}
\hline & PC\#1 & $\mathrm{PC} \# 2$ & & \\
\hline Parameter & p1 & $\mathrm{p} 2$ & $\mathrm{p} 1^{*}$ & D-coeff. \\
\hline Temp. & 0.06 & 0.12 & 0.18 & 0.28 \\
\hline Smell & 0.32 & 0.21 & 0.75 & 1.14 \\
\hline No blood & -0.31 & -0.04 & -0.67 & -1.02 \\
\hline Pink & 0.21 & 0.13 & 0.70 & 1.06 \\
\hline Brownish & 0.19 & -0.05 & 0.49 & 0.74 \\
\hline Watery & 0.05 & 0.33 & 0.23 & 0.35 \\
\hline Semi-visc & 0.38 & -0.20 & 0.76 & 1.15 \\
\hline Mucus-like & -0.40 & 0.04 & -0.81 & -1.22 \\
\hline amount1 & -0.31 & 0.07 & -0.63 & -0.96 \\
\hline amount2 & 0.09 & -0.53 & 0.21 & 0.32 \\
\hline amount3 & 0.23 & 0.41 & 0.54 & 0.82 \\
\hline pus0 & -0.32 & 0.20 & -1.70 & -1.06 \\
\hline pus1 & -0.07 & 0.12 & -0.20 & -0.30 \\
\hline pus2 & 0.06 & -0.46 & 0.15 & 0.23 \\
\hline pus3 & 0.32 & 0.13 & 0.71 & 1.07 \\
\hline Offset & & & -7.029 & -6.41 \\
\hline
\end{tabular}

significant effect of index group on the slope of the regression, i.e. the rate of uterine involution. When both slope and intercept effects of index group were included in the regression of cervix diameter on DFC, neither was significant.

When the regression model was simplified by removing the effect of index group on slope, a significant difference in intercept was found, where the high-index group had a greater intercept. Overall, high-index cows had a delayed uterine involution since at any given time from calving both cervix and pregnant horn diameter was greater in high-index cows (Table 4).

\section{Uterine involution in all animals}

The next test of uterine involution was performed using all animals. The maximum value of the D-index within 21 days after calving (maxD-index) was used as a constant value of uterine inflammation. Values of

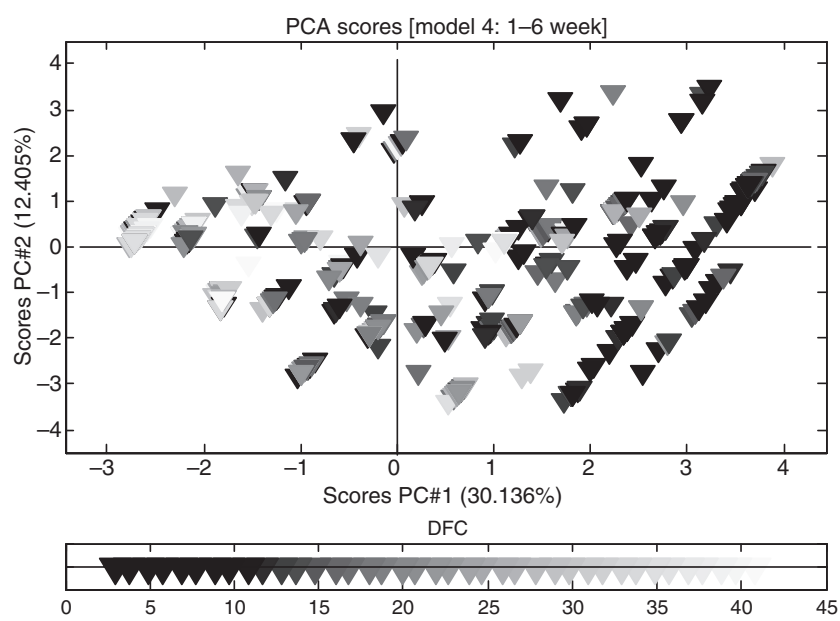

Fig. 4. Scores plot shaded according to days from calving (DFC). The shading scale is shown below the main plot

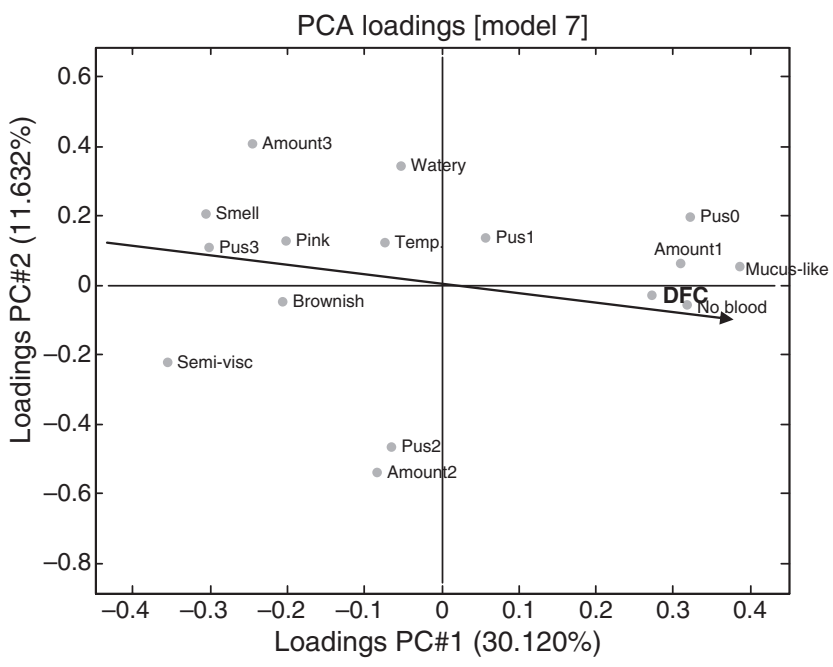

Fig. 5. Adding the variable 'DFC' does not change the PCA model. It shows that the proportion of cows having 'not clean uterus' decreases with time. Due to the rotational ambiguity of PCA, the sign of the loadings is reversed when compared with the model without 'DFC'

D-index after 21 days postpartum would not significantly influence the rate of uterine involution, because most of the process is already completed (Morrow et al. 1966; Gier and Marion 1968).

There was a significantly greater intercept for increasing values of maxD-index in the regression of uterine cervix and pregnant horn on DFC (Table 5). There was also a significant effect of maxD-index on the slope (i.e. involution rate) in the regression of pregnant horn, but not in the regression of uterine cervix.

Overall, at any given time, cows with a higher maxDindex had a significantly delayed involution of uterine cervix and pregnant horn and significantly slowed down the rate of involution of pregnant horn.

\section{Discussion}

In this study, clinical findings of dairy cows during the postpartum period were described and related, using a multivariate statistical model. The overall purpose was to identify the key combinations of uterine discharge symptoms and their severity, which possible reflect degrees of uterine inflammation, since it has been shown that uterine discharge reflects well the bacterial uterine infection and immune response (Williams et al. 2005). To achieve this, a PCA model was designed and used. This is the first time a multivariate PCA approach has been applied to uterine discharge symptoms.

Using this approach, and deconstructing symptoms into classes to avoid making assumptions about the symptom's scales, the PCA analysis provided the basis for building a simple score. The constructed discharge index (D-index) gives a continuous value between 0 and 10. Calculated D-coefficients are ready for use under field conditions. To obtain the D-index value, the vaginal discharge needs to be scored as indicated in the methods section (Table 1). Then the D-index value is created by summing the D-coefficients for each discharge feature, rectal temperature and offset (Table 3). Notice that rectal temperature, as a non-class variable, 


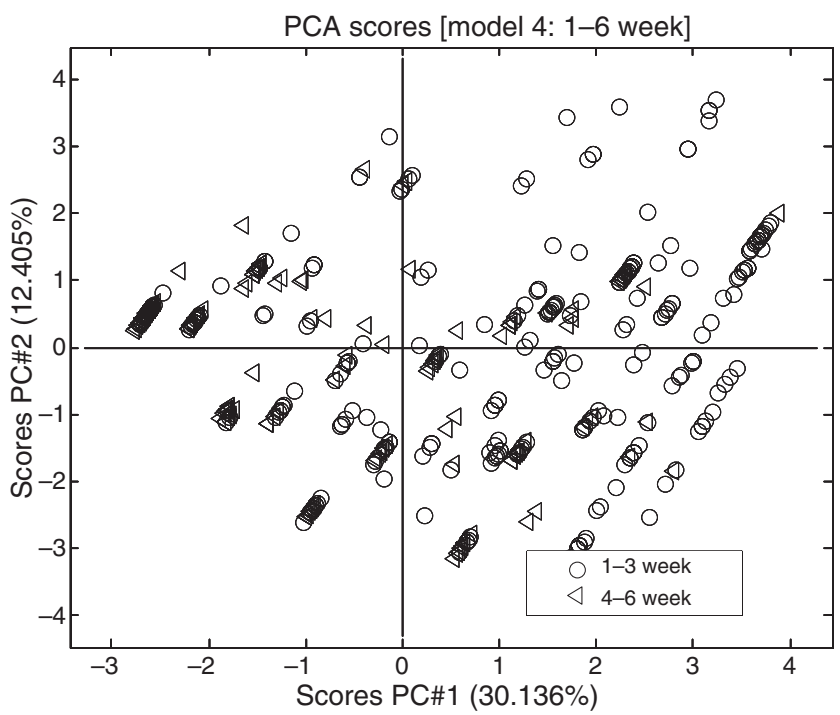

Fig. 6. Scores plot dividing observations into two time intervals: weeks $1-3$ and 4-6

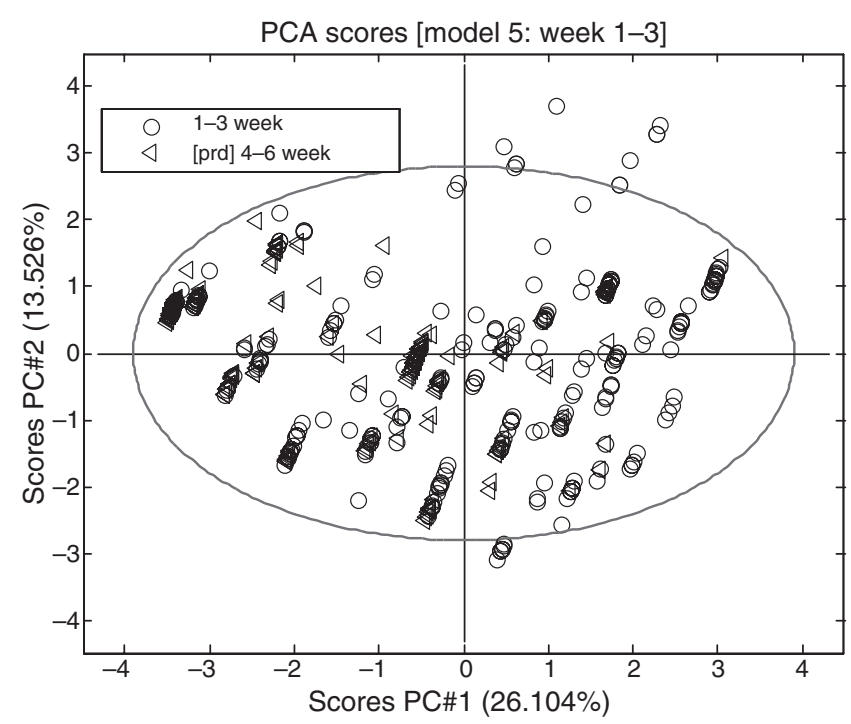

Fig. 7. Scores for weeks 4-6 were predicted on the basis of the model for weeks $1-3$. The model is stable across time, because all predicted objects from weeks 4-6 remain in the ellipse, which shows a $95 \%$ confidence interval

needs to be first multiplied with D-coefficient. Notice also that after the simplification of the model, the discharge colours red, brown and black have the same D-coefficient ('brownish'). For example, a cow recorded as: pus3, amount3, consistency-semi-viscous, smell-yes, colour-pink and temperature $39.5^{\circ} \mathrm{C}$ will have a D-index value $=9.89$ (see Table 6$)$.

At first glance calculating of the value of D-index may seem to be complicated, but it mainly consists of adding the coefficients. In the light of easy access to on-farm hand held recorders/calculators, etc., the added complexity is not seen as being a serious drawback given the advantages of the additional information provided by the D-index. The D-index can be used without any adjustment at any time from calving (up to 6 weeks

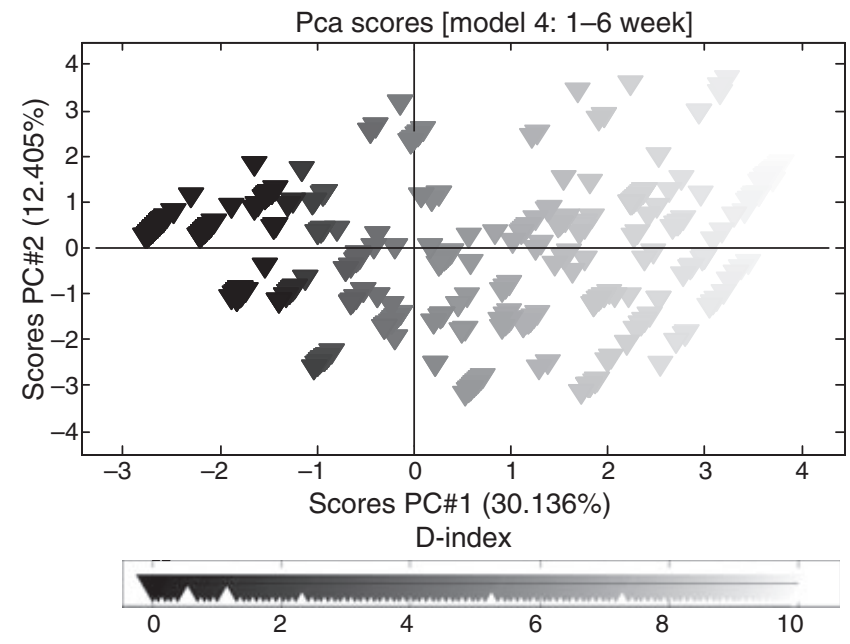

Fig. 8. PCA-scores shaded according to the value of the discharge index (D-index). The shading scale is given below the main plot

Table 4. The relationship $\ln (\mathrm{Y})=\ln (\mathrm{a})+\ln (\mathrm{k}) \inf +\mathrm{b} \times \mathrm{t}+1 \times$ inf $\times \mathrm{t}$ between uterine involution and time as affected by $\mathrm{D}$-index group (inf $=0$ for low-D-index and inf $=1$ for high-D-index)

\begin{tabular}{|c|c|c|c|c|c|c|}
\hline $\ln (Y)$ & $\ln (a)$ & $b$ & $\ln (k)$ & $l$ & $R^{2}$ & $\begin{array}{c}\text { Residual } \\
\text { st.dev. }\end{array}$ \\
\hline $\begin{array}{l}\text { Pregnant } \\
\text { horn } \\
\text { involution }\end{array}$ & $\begin{array}{c}1.64 \\
\mathrm{p}=0.000\end{array}$ & $\begin{array}{c}-0.0147 \\
\mathrm{p}=0.000\end{array}$ & $\begin{array}{c}0.208 \\
\mathrm{p}=0.021\end{array}$ & $\begin{array}{c}-0.00646 \\
\mathrm{p}=0.059\end{array}$ & 0.5 & 0.1974 \\
\hline $\begin{array}{l}\text { Cervix } \\
\text { Involution }\end{array}$ & $\begin{array}{c}1.87 \\
\mathrm{p}=0.000\end{array}$ & $\begin{array}{c}-0.0175 \\
\mathrm{p}=0.000\end{array}$ & $\begin{array}{c}0.0381 \\
\mathrm{p}=0.447\end{array}$ & $\begin{array}{c}0.00166 \\
\mathrm{p}=0.409\end{array}$ & 0.66 & 0.1377 \\
\hline $\begin{array}{l}\text { Cervix } \\
\text { Involution }\end{array}$ & $\begin{array}{c}1.85 \\
\mathrm{p}=0.000\end{array}$ & $\begin{array}{c}-0.0166 \\
\mathrm{p}=0.000\end{array}$ & $\begin{array}{c}0.0750 \\
\mathrm{p}=0.001\end{array}$ & - & 0.66 & 0.1375 \\
\hline
\end{tabular}

Table 5. The relationship $\ln (\mathrm{Y})=\ln (\mathrm{a})+\mathrm{b} \times \mathrm{t}+\mathrm{k} \times \operatorname{maxD}$ index $+1 \times$ maxD-index $\times t$ between uterine involution and time as affected by maximum value of $\mathrm{D}$-index within 21 days after calving

\begin{tabular}{lcccccc}
\hline $\ln (Y)$ & $\ln (a)$ & $B$ & $\ln (k)$ & $l$ & $R^{2}$ & $\begin{array}{c}\text { Residual } \\
\text { st.dev. }\end{array}$ \\
\hline $\begin{array}{c}\text { Pregnant horn } \\
\text { involution }\end{array}$ & $\begin{array}{c}1.57 \\
\mathrm{p}=0.000\end{array}$ & $\begin{array}{c}-0.0122 \\
\mathrm{p}=0.000\end{array}$ & $\begin{array}{c}0.0263 \\
\mathrm{p}=0.003\end{array}$ & $\begin{array}{c}-0.000792 \\
\mathrm{p}=0.017\end{array}$ & 0.43 & 0.2081 \\
$\begin{array}{c}\text { Cervix } \\
\text { Involution }\end{array}$ & $\mathrm{p}=0.000$ & $\mathrm{p}=0000$ & $\mathrm{p}=0.042$ & $\mathrm{p}=0.000171$ & 0.60 & 0.1431 \\
\hline
\end{tabular}

post-calving), because time from calving (DFC) did not influence the model, it remained stable across time. Time is correlated with uterine infection but is not a cause of the disease. It is a condition of the animal associated with suppressed immunity after calving, which predisposes to a higher risk of uterine infection, especially in the first 3 weeks postpartum (Mallard et al. 1998; Burton et al. 2005).

Using PCA analysis, it became clear how uterine discharge features relate to each other and how they cluster together, possibly representing different degrees of uterine inflammation. The lowest $\mathrm{D}$-index values are associated with pus0, amount1, no-blood and mucus like consistency, which are strongly correlated. Discharges with flecks of pus (pus1) give higher D-index values between 3 and 4 . This feature is not correlated with others, but is localized on the border between 
Table 6. Example of calculation of D-index value for uterine discharge

\begin{tabular}{lc}
\hline Parameter & D-coefficient \\
\hline pus3 & 1.07 \\
Amount3 & 0.82 \\
Consistency: semi-viscous & 1.15 \\
Smell - yes & 1.14 \\
Colour: pink & 1.06 \\
Temperature: 39.5 & $39.5 \times 0.28=11.06$ \\
Offset & -6.41 \\
& D-index $=9.89$ \\
\hline
\end{tabular}

'clean' and 'not clean' uterus indicating an increasing process of inflammation. The next two clusters of features have a similar D-index value between 4 and 6 , and these are clusters: pus2 correlated with amount2 and watery discharge correlated with high temperature. This second group, when associated with brownish colour, is defined in the literature as puerperal metritis. The highest D-index values have discharges with a strong correlation between pus 3 and fetid smell, which is associated with amount3, semi-viscous consistency and sometimes pink colour (haemorrhagic discharge). The brownish colour feature is not strongly correlated with other features, but its localization between other clusters means that it may be associated with high temperature and watery discharge (puerperal metritis), pus2 correlated with amount2, semi-viscous consistency, or with the group with amount3, pus3 and fetid smell. All these different combinations occur especially often in the two first weeks after calving.

In the current study, only the first principal component was used to create the D-index as it contrasts the symptoms of 'clean uterus' with 'not clean uterus'. However, further PCs may bring additional, more detailed information about uterine inflammation. They account for lower percent of total variance and describe less important and smaller combinations of uterine discharge symptoms. $\mathrm{PC \# 2}$ in this model contrasts cluster pus 2 and amount 2 with amount 3 and watery consistency.

The combination of discharge symptoms in the PCA model may be related to different types of uterine infection, which have been described before in the literature (Sheldon et al. 2006). In order to establish if one scoring scale could be made across time, no attempt was made in this study to differentiate between the types of uterine infection, only severity of discharge symptoms was assessed. This permitted us to obtain one number, the D-index, on a continuous scale, which possibly reflects the uterine inflammation process.

In this paper, the D-index was tested by using the data of the uterine involution process. It is generally known that uterine infection may negatively affect involution (Morrow et al. 1969; Hajurka et al. 2005). Most of this process is completed within 3 weeks after calving (Morrow et al. 1966; Gier and Marion 1968), therefore, a maximum value of the discharge index within 21 days was used as a potential factor affecting the involution. Uterine involution was significantly delayed in the highD-index group of cows indicating that the D-index correctly described the known effect of uterine inflammation on involution. Similarly, in the test with all cows, involution was progressively delayed and the rate of involution of pregnant horn was slowed down with the increase of the D-index values.

Postpartum contamination of the uterus is ubiquitous in dairy cows (Sheldon et al. 2008), but it does not mean that any type of discharge within the first 3 weeks after calving is acceptable. In this PCA model, only about half of the observations had 'not clean' uterus with a high D-index score for the first 3 weeks after calving. These cows had a delayed involution process, compared with low-D-index animals. It may be that, among other factors, breed and hygienic conditions influence the prevalence of contaminated animals. The incidence of positive bacterial cultures varies in normal calving cows, e.g. Griffin et al. (1974) $96 \%$ of normal cows, Bekana et al. (1996) $22 \%$ of normal cows, Kask et al. (1999) $33 \%$ of normal cows. Unhygienic conditions may increase the bacterial contamination of the vestibulum and vagina, and the bacteria can than easily migrate to the uterus after parturition (Bretzlaff et al. 1982).

In the examined herd, there were high hygienic standards, which may explain the better than average uterine health. Also, Danish Jersey cows were more resistant to both contamination in the early period and infection in the late period than Danish Holstein cows.

In future investigations the authors hope to use the D-index to assess the extent of the relationship between the clinical symptoms of uterine inflammation and ovarian activity.

\section{Conclusions}

This study provided for the first time a continuous scale for severity of uterine inflammation clinical symptoms. This scale is universal for any type of uterine discharge, any type of uterine infection associated with the presence of the discharge in vagina (defined in the literature as puerperal metritis, metritis, clinical metritis, clinical endometritis) and for any time up to 6 weeks after calving. The scale was built without any assumptions about the correlations between discharge features and thus reflects degree of uterine inflammation based on the natural, biological pattern.

\section{Acknowledgements}

The paper is a part of a PhD project funded by the Danish Research Council, Aarhus University, the Faculty of Agricultural Sciences and Lattec I/S. The authors would like to thank Kurt Myrup Pedersen for helpful comments and general support.

\section{Conflict of interests}

The authors report a financial relationship with Lattec I/S. We declare that Lattec I/S had no involvement in the conception, implementation or reporting of this work.

\section{Author contributions}

Justyna Gorzecka has designed study, collected data, analyzed data, drafted paper. Nicolas Friggens has designed study, analyzed data, 
drafted paper. Carsten Ridder has analyzed data, drafted paper. Henrik Callesen has designed study, drafted paper.

\section{References}

Battaglia DF, Krasa HB, Padmanabhan V, Viguie C, Karsch FJ, 2000: Endocrine alterations that underlie endotoxininduced disruption of the follicular phase in ewes. Biol Reprod 62, 45-53.

Bekana M, Jonsson P, Kindahl H, 1996: Intrauterine bacterial findings and hormonal profiles in post-partum cows with normal puerperium. Acta Vet Scand 7, 251-263.

Borsberry S, Dobson H, 1989: Periparturient diseases and their effect on reproductive performance in five dairy herds. Vet Rec 124, 217-219.

Bretzlaff KN, 1987: Rationale for treatment of endometritis in the dairy cow. Vet Clin N Am Food Anim Prac 3, 593607.

Bretzlaff KN, Whitmore HL, Spahr SL, Ott RS, 1982: Incidence and treatments of postpartum reproductive problems in a dairy herd. Theriogenology 17, 527-535.

Burton JL, Madsen SA, Chang LC, Weber PSD, Buckham KR, van Dorp R, Hickey MC, Earley B, 2005: Gene expression signatures in neutrophils exposed to glucocorticoids: A new paradigm to help explain "neutrophil dysfunction" in parturient dairy cows. Vet Immunol Immunopathol 105, 197-219.

Dohmen MJW, Lohuis JACM, Huszenicza G, Nagy P, Gacs M, 1995: The relationship between bacteriological and clinical findings in cows with subacute/chronic endometritis. Theriogenology 43, 1379-1388.

Esbensen KH, 2002: Multivariate data analysis-in practice. An introduction to multivariate data analysis and experimental design. 5th edn CAMO Process AS, Oslo.

Gier HT, Marion GB, 1968: Uterus of the cow after parturition:involutional changes. Am J Vet Res 29, 83-96.

Griffin JFT, Hartigan PJ, Nunn WR, 1974: Non-specific uterine infection and bovine fertility : I. Infection patterns and endometritis during the first seven weeks post-partum. Theriogenology 1, 91-106.

Hajurka J, Macak V, Hura V, 2005: Influence of health status of reproductive organs on uterine involution in dairy cows. Bull Vet Inst Pulawy 49, 53-58.

Herath S, Williams EJ, Lilly ST, Gilbert RO, Dobson H, Bryant CE, Sheldon IM, 2007: Ovarian follicular cells have innate immune capabilities that modulate their endocrine function. J Reprod Fertil 134, 683-693.

Huszenicza G, Fodor M, Gacs M, Kulcsar M, Dohmen MJW, Vamos M, Porkolab L, Kegl T, Bartyik J, Lohuis JACM, Janosi S, Szita G, 1999: Uterine bacteriology, resumption of cyclic ovarian activity and fertility in postpartum cows kept in large-scale dairy herds. Reprod Domest Anim 34, 237-245.

Jackson JE, 1991: A User's guide to Principal Components. John Wiley \& Sons, New York.

Kask K, Gustafsson H, Magnusson U, Bertilsson J, Gunnarsson A, Kindahl H, 1999: Uterine bacteriology, histology, resumption of ovarian activity and granulocyte function of the postpartum cows in different milking frequencies. Acta Vet Scand 40, 287-297.

LeBlanc SJ, Duffield TF, Leslie KE, Bateman KG, Keefe GP, Walton JS, Johnson WH, 2002: Defining and diagnosing postpartum clinical endometritis and its impact on reproductive performance in dairy cows. J Dairy Sci 85, 2223 2236.

Mallard BA, Dekkers JC, Ireland MJ, Leslie KE, Sharif S, Vankampen CL, Wagter L, Wilkie BN, 1998: Alteration in immune responsiveness during the peripartum period and its ramification on dairy cow and calf health. J Dairy Sci 81, 585-595.

Miller A. N., Herath S., Bryant C. E., Jost B. H., Billington S. J., Sheldon I. M. 2007: Arcanobacter Pyogenes Pyolysin Stimulates Bovine Endometrial Cell Prostaglandin Secretion. British Society of Animal Science, Conference: "Fertility in Dairy Cows-bridging the Gaps", 30-31 August 2007, and Liverpool University, United Kingdom, pp. 38.

Morrow DA, Roberts SJ, McEntee K, Gray HG, 1966: Postpartum ovarian activity and uterine involution in dairy cattle. J Am Vet Med Ass 149, 1596-1609.

Morrow DA, Roberts SJ, McEntee K, 1969: A review of postpartum ovarian activity and involution of the uterus and cervix in cattle. Cornell Vet 59, 134-154.

Murray RD, Allison JD, Gard RP, 1990: Bovine endometritis: comparative efficacy of alfaprostol and intrauterine therapies, and other factors influencing clinical success. Vet Rec 127, 86-90.

Sheldon IM, Dobson H, 2004: Postpartum uterine health in cattle. Anim Reprod Sci 82 83, 295-306.

Sheldon IM, Noakes DE, 1998: Comparison of three treatments for bovine endometritis. Vet Rec 142, 575-579.

Sheldon IM, Noakes DE, Rycroft AN, Pfeiffer DU, Dobson H, 2002: Influence of uterine bacterial contamination after parturition on ovarian dominant follicle selection and follicle growth and function in cattle. J Reprod Fertil 123, 837-845.

Sheldon IM, Lewis GS, LeBlanc S, Gilbert RO, 2006: Defining postpartum uterine disease in cattle. Theriogenology $\mathbf{6 5}$, $1516-1530$.

Sheldon IM, Williams EJ, Miller ANA, Nash DM, Herath S, 2008: Uterine diseases in cattle after parturition. Vet J 176, $115-121$

Williams EJ, Fischer DP, Pfeiffer DU, England GCW, Noakes DE, Dobson H, Sheldon IM, 2005: Clinical evaluation of postpartum vaginal mucus reflects uterine bacterial infection and the immune response in cattle. Theriogenology $\mathbf{6 3}, 102$ 117

Wise B. M., Gallagher N. B. 2000: PLS_Toolbox 2.1 for use with MATLAB(TM).

Submitted: 6 Oct 2009; Accepted: 29 Jan 2010

Author's address (for correspondence): J Gorzecka, Faculty of Agricultural Sciences, Department of Animal Health and Bioscience, Group of Integrative Physiology, Aarhus University, Tjele, Denmark. E-mail: justyna.gorzecka@agrsci.dk 